\title{
HERMANN KLAATSCH AND THE TIWI, 1906
}

\author{
Brigitte Stehlik
}

The following early account of the Tiwi was written by Hermann Klaatsch, a German physical anthropologist, who visited the Tiwi in 1906, one of the 'major points' of his three years of travels in Australia. In the report, originally written in German, Klaatsch gives us a lively and informative narrative of his stay among the Tiwi of Melville Island, whom he calls Melvillians'. He refers to many facets of their life and culture and he is the first to draw attention to the Tiwi graveposts.

Klaatsch's account of Melville Island forms part of his final report ('Schlussbericht'), the outcome in writing of a talk he delivered to the Berlin Anthropological Society after returning from Australia. It is contained in Zeitschrift für Ethnologie, where his various reports and letters from Australia were published. ${ }^{1}$ During his travels Klaatsch was financially supported by the Royal Academy of Sciences in Berlin (Königliche Akademie der Wissenschaften).

Who was Hermann Klaatsch? He was born in Berlin in 1863. Coming from a family of medical doctors, with his father, grandfather, and also ancestors of his mother being renowned doctors, it is not surprising to find him developing an early interest in natural science. This had already become apparent when, as a boy of six, he was included in the list of donors of the Berlin Aquarium because he had delivered to it his collection of reptiles, the result of his holiday activities.

He studied medicine in Heidelberg and Berlin, specialising in anatomy as a student of Gegenbaur and Waldeyer, both renowned professors of anatomy. He became Waldeyer's assistant in Berlin, and in 1895 Associate Professor of Anatomy in Heidelberg. After 1904 he spent three years travelling, mostly in Australia. After his return he became Professor of Anatomy, Anthropology and Ethnography at the University of Breslau (now called Wroclav, in Poland), a position he held up to his death in 1916, at the age of fifty-three. He died of complications connected with the malaria he had contracted on his travels.

Klaatsch's reasons for travelling to Australia are directly connected with his scientific interests and these, in turn, are linked with his originality of thought. He was a keen worker, dedicated to finding truth. Friends praised his originality, his geniality, his imagination, enemies feared his piercing questions, his disregard of established opinions and theories, even those of eminent authorities. If the results of his own research, considered true by him, contradicted an existing theory, he would create a new one to match the facts, always prepared to rearrange the theory in the light of new findings. For him, facts that were not put into a theoretical framework were worthless 'ballast'.

Brigitte Stehlik has an MA in anthropology (Berlin) as well as a translator's degree, and is affiliated with the Museum für V'llkerkande in Berlin.

1 Vols 37-39, 1905-1907. 
In the first years of his career he worked in the field of comparative anatomy, frequently on problems connected with questions of evolution. The results of his comparative anatomical research on various animal species led him to create his own theory of the evolution of mankind, which he presented at a conference in $1899 .^{2}$ However, he could convince few people of the truth of his theory. In connection with his thoughts on the development of mankind he was deeply concerned with learning about early man. He was engaged in the work that led to the recognition of the true status of Neandertal Man and excavated various specimens of early man, such as Homo mousteriensis and Homo aurignacensis, an area in which he was a widely recognised authority. ${ }^{3}$

[Klaatsch was actually present when Otto Hauser excavated the Le Moustier skeleton, and the two of them co-authored a new description, calling it Homo mousteriensis hauseri; they were aware it was of Neandertal type, but considered it somewhat different from standard Neandertalers. The form of the name is confusing: they probably intended the scientific name to be H.mousteriensis, with hauseri meaning just that Hauser had discovered it; this is more or less supported by the fact that Klaatsch later on did just refer to a Homo mousteriensis. Homo aurignacensis refers to another of Hauser's discoveries, the Combe-Capelle skull, which Klaatsch and Hauser co-described as Homo aurignacensis hauseri in 1910. They thought that the skull's rugged features placed it in an intermediate category between Neandertal and modern. It is nowadays clear that it is a perfectly modern (even Europeantype) specimen. The tag hauseri to the specific name again seems to indicate nothing more than that it was discovered by Hauser, and it would seem quite certain that the name was meant to be H.aurignacensis. ${ }^{4}$ ]

In connection with the skull of the Neandertal Man, the English anatomist T.H. Huxley, as early as 1863 , drew attention to the similarity of its protruding browridges (Klaatsch calls them supraorbital arches) to some crania of Australian Aborigines. This similarity, plus the fact that very early hominid remains, Pithecanthropus, had been discovered in Java, and the similarity of many physical features of Aborigines to modern Europeans and other modern populations, led him to formulate the idea of the 'Australoid roots of mankind', published by him in $1903 .^{5}$ In this hypothesis too he had few followers.

Another of his ideas was, however, in line with the thoughts of most other evolutionists of his time: that hunters and gatherers represented an earlier, primitive, lower stage in the development of mankind; they were seen as being in the stage of youth or childhood, whereas modern Europeans represented the adult, mature, responsible stage of mankind. Evolutionists believed in this 'early', 'savage' stage not only physically, but also culturally or psychologically.

Klaatsch thus believed that by studying Australian Aborigines - in his opinion the 'Urstamm der Menschheit' (primaeval tribe of mankind) - he would gain insights into the

2 See Heilborn in Klaatsch 1922:xxi ff.

3 The following paragraph is based on material kindly supplied by Colin Groves.

4 See Klaatsch and Hauser 1909 and 1910.

5 1903:335. 
way of life and way of thought of early races of man, and would learn about the origins of culture in general. The above-mentioned ideas motivated Hermann Klaatsch to travel to Australia and to study its original inhabitants from the physical and cultural points of view. However, in spite of his preconceived ideas about the 'primitivity' of Aborigines, his stay among them gave him an emotional, almost romantic, attachment to them. This becomes apparent in his statement:

The sight of the adult male body is aesthetically pleasing, the posture is proud ... When you see the black man walking by, with his erect posture, his head decorated with feathers, with the spear in his right hand, then you cannot help form the impression that you have a 'savage gentleman' in front of your eyes, a king in the realm of the surrounding nature, to which he is so well adapted. How much like a slave and how despicable appears the small Malay, in contrast to him! $!^{6}$

During his extensive travels in Australia Klaatsch collected an immense amount of data, which, in his own words, would take him years to evaluate. ${ }^{7}$ However, after his return, his palaeontological work on early man in Europe absorbed most of his time. Apart from the above-mentioned reports in Zeitschrift für Ethnologie, only minor publications containing ethnographic material on Aborigines appeared (especially 1911 and 1913). His final major work with the title Der Werdegang der Menschheit und die Entstehung der Kultur (The evolution of humanity and the emergence of culture), published posthumously, refers frequently to Australia and contains twenty-five of his Australian photographs. But his sudden death at the age of fifty-three prevented him from completing the more comprehensive work on Australia on which he was working. ${ }^{8}$ In spite of his outdated or unusual thoughts, his writings retain their value because of their lively style, the wealth of ideas and the questions asked.

\section{A Summary of Klaatsch's Australian Travels.}

His journey started on 9 February 1904 in Genoa. After twenty-six days he landed in Perth, then continued by sea to Brisbane where he arrived on 21 March 1904 . He spent seven weeks in Brisbane, dedicating most of this time to the study of the private collection of W.E. Roth, who at that time was Protector of Aborigines in Queensland. His collection included both material culture and skeletal material, including crania, from northern Queensland, the latter being Klaatsch's primary field of study. He was to spend an entire year in Queensland.

On 17 May 1904 he left Brisbane by ship, travelling north, making shorter visits to various towns and districts. He spent one month on 'Silver Valley', near Herberton, where he was able to make his first studies of living Aborigines. He also visited Yarrabah mission station, near Cairns. On Thursday Island a government boat was made available to him to take him to the Gulf of Carpentaria. He visited Mapoon Mission on the Batavia River, and then

6 1907b:80.

7 ibid.

8 Heilborn in Klaatsch 1922:xxx.

9 The most complete list of his writings, listing 81 publications, is included in Wegner 1915-1916. 
continued to the Archer River, accompanied by the German missionary from Mapoon, Herr Richter. On the Archer River he came into contact for the first time with 'really wild natives' as he calls them. ${ }^{10}$ He left Archer River on 12 August 1904, travelling via Karumba to Sweers, Bentinck and Bayley Islands. Then he spent more than two weeks in Normanton. From there he left by boat for Burketown, on the Albert River, made a twelve-day excursion along the Leichhardt River, then continued by boat via Thursday Island to Cooktown, and also visited the nearby mission station at Cape Bedford.

He spent more than two months in the Cairns area, making excursions also to the Bellenden Ker Mountains, where he obtained a mummy, ${ }^{11}$ and to the lower reaches of the Russell River and its tributaries. He also paid another visit to the Yarrabah mission station.

On 1 February 1905 he left Cairns again, making short visits to other towns and spending twelve days on Fraser Island. He remained another eleven days in Brisbane, where he carried out studies at the Museum and frequently met with Roth, with whom he had become friends and whose anthropological work he respected highly.

After leaving Queensland he arrived in Sydney on 24 March 1905; he was to stay there for the next five months. He studied in libraries, but most of his time was spent at the Australian Museum, where he continued his anatomical studies of the skulls of the Roth collection, which in the meantime had been acquired by the Museum.

During his stay in Queensland, as well as during the rest of his travels in other areas of Australia, he was active in assembling a collection of ethnographical objects. He also collected stone artefacts. However, due to his scientific background in anatomy, his primary interest was physical anthropology. Wherever he could, mostly in prisons and on mission stations, he took physical measurements of Aborigines. He also assembled an anatomical collection. At times his keen scientific interests even led him to open up graves; acts which, not surprisingly, caused occasional personal difficulties for him. Thus he had a hasty departure from Normanton in Queensland, when the Aborigines considered him 'Devil-Devil' and wanted to spear him.

After a long stay in Sydney Klaatsch left on 2 September 1905 for Melbourne, continuing directly to Warrnambool. Here he wanted to get an immediate impression of the sandstone quarry, where ancient animal footprints and controversial human footprints had been found. He discovered the footprints of the extinct Australian giant bird Genyornis newtoni. ${ }^{12} \mathrm{He}$ believed the human footprints to be those of a young male person. ${ }^{13}$ When he was planning his visit to the site other scholars in Sydney and Melbourne had thought it 'a waste of time and money'. 14

From Melbourne he continued to Adelaide, then travelled from there by ship to Perth, arriving on 1 October 1905 . While in the Perth area he made anatomical studies, taking measurements of Aboriginal inmates of a prison on Rottnest Island, and shortly afterwards measuring prisoners at Roebourne.

10 1905:213.

11 Described in detail in Klaatsch 1911:415 ff.

12 For photograph see Klaatsch 1906:796.

13 Klaatsch 1907b:80 ff; for photograph see Klaatsch 1906:782.

14 Klaatsch 1906:776. 
From Perth he headed north by boat towards Broome, and remained in that area for over a month. On the mission station close to Beagle Bay he had an opportunity to study the Niol-Niol (Nyul-Nyul). He had a good relationship with the Catholic missionaries there, whose work he judged more favourably than that of some missionaries in Queensland, where coercion was more frequently applied.

On 12 December 1905 he left Australia (Broome) in order to visit Java. His main reasons for visiting Java were to examine personally the extremely early hominid skeletal remains and the site of Pithecanthropus, which had been discovered there in 1891. Moreover, he wanted to find out whether he could discern there any signs of an earlier, pre-Malay population. The results in the latter respect were negative. He was very unfortunate in acquiring a bad case of malaria, which forced him to return to Australia, hoping that its dry climate would help him regain his health.

After five months' absence from Australia he returned to Broome on 21 May $1906 . \mathrm{He}$ had to remain in the hospital there for three weeks - a time which from the anatomical point of view proved to be very successful as it offered him opportunities to acquire human remains (brains) for his collection. He then returned to Beagle Bay to resume his ethnographic studies among the Niol-Niol. He was especially keen on finding out with certainty whether a system of totems prevailed there of the same complicated type as had been described recently for Central Australian tribes. ${ }^{15}$ His results were negative: the Niol-Niol did not have totems as described for the Arunta. In a lengthy discussion of this topic he criticised the overly wide and extended use of the term totemism, saying that too frequently it was used for concepts and traditions that lacked a wide enough common basis. ${ }^{16} \mathrm{He}$ describes a conversation with Gillen in Adelaide, where he informed him of his negative results: 'He was extremely astonished about my failure and regretted not having gone himself to northwestern Australia as he would surely have found totems. "I don't doubt this for one moment", I replied'. ${ }^{17}$ Referring to the Niol-Niol he noted the great importance of the churingas, the special role of the great water snake Wallangan, mentioned marriage classes and spoke of their connection with those of Central Australian tribes.

On 7 July 1906 he continued to Wyndham, via Derby. He had to stay there for two months, awaiting the departure of the next boat to Darwin. Here he suffered a new attack of malaria, only recovering towards the end of this time. In the prison at Wyndham he was able to take anatomical measurements of over seventy Aboriginal prisoners. By maintaining close contact with the doctor, who informed him of new deaths, he had a chance to increase his anatomical collection.

During his two months in Wyndham he had ample opportunity to observe the harsh treatment of the Aboriginal population by Europeans. He saw how twenty-two men were transported to Wyndham, tied to one another with chains around the neck. ${ }^{18}$ In a letter he wrote:

15 Spencer and Gillen 1899. and 1904.

16 Klaatsch 1906:796; 1907a:636 ff.

17 Klaatsch 1907a:638.

18 See photographs in Klaatsch 1907a: plates 7 and 8. 
these poor savages are getting caught by the police because of the alleged crime of having speared cattle. The policemen get paid per head and take along as many as possible. Considering our modern, supposedly high culture and "Christian' morals it is an unheard-of cruelty that these innocent children of the wilderness have to carry out hard labour, tied with chains to one another, until death relieves them. Those who survive this ordeal, however, get transported back to their homelands. ${ }^{19}$

After leaving Wyndham he made a short stop at Port Keats, and then arrived in Darwin in the middle of September 1906. There he noted the more friendly relations prevailing between the old and new inhabitants of the country. From Darwin Klaatsch set out for his expedition to Melville Island, the report of which is translated below. It lasted from 17 September to 1 October 1906.

Back in the Darwin area he had friendly contact with the Larrikia and Kunandja or 'Alligator River tribe'. He also successfully collected items of material culture. He then returned directly to Sydney by ship, arriving on 19 November 1906, and so completing the circumnavigation of Australia for which he had set out fourteen months earlier. He gave talks about his journey, contacted 'the gentlemen of the university' and had his previous work on skulls accepted for publication. ${ }^{20}$

On 22 December he left Sydney for Tasmania, where he examined anthropological material at the museum in Hobart. From there he continued to Adelaide in order to attend a meeting of the Australian Association for the Advancement of Science, at which he gave a talk which was published in English. ${ }^{21}$ It was on this occasion that the above-mentioned meeting with Gillen took place. After another stopover in Hobart he arrived in Sydney on 7 February 1907.

During his last few days in Australia he received the offer of a chair in Anatomy, Anthropology and Ethnography at the University of Breslau, which he gladly accepted. He left Sydney on 18 February 1907, returning to Germany via Canada and finally arriving in Bremerhaven on 3 April 1907.

During his three years abroad Klaatsch had assembled an impressive collection of ethnographic material, comprising altogether 2,300 objects. These were temporarily shown in an exhibition which opened on 7 September 1907 in the Rautenstrauch-Jöst-Museum für Volkerkunde in Cologne. Afterwards the ethnographic collections were distributed to other museums, the greater part being kept in the Ethnological Museums of Hamburg, Leipzig and Cologne. His collection of stone artefacts went to Breslau. 22

19 1906:800.

20 See Klaatsch 1908.

21 Klaatsch $1907 \mathrm{c}$.

22 Gesela Voelger, Director of the Cologne Rautenstrauch J"öst Museum, is preparing a paper on the Klaatsch collections which may also contain information on the whereabouts of his anatomical collection (described briefly in Klaatsch $1907 \mathrm{~b}: 2$ ). 


\title{
KLAATSCH'S ACCOUNT OF AN EXPEDITION
}

\author{
TO MELVILLE ISLAND IN $1906^{23}$
}

A major point of my program was the journey to Melville Island. This northernmost island of Australia is separated from the mainland by a strait of only forty English miles; with respect to its fauna and flora it belongs completely to the mainland, from which it apparently separated only in a relatively late period. In the year 1824 an English military settlement was founded there (Fort Dundas) which, however, had already been abandoned in 1829 because the unhealthy climate and the hostility of the natives had made the stay on the lonely island very unpleasant. Since this time, the blacks [schwarzen] on Melville Island have been left to themselves and, forming a considerable-sized group (they are estimated at about one thousand head), they are living in their original savage ways. They are considered to be treacherous and bloodthirsty, and this is the reason why only a few Europeans dare to venture into the interior of the island. Even a government geological expedition in the year 1905 limited itself to a minimal visit to the coast and did not see a single native.

The only value that Melville Island has at the present time is in the big herds of wild cattle, descendants of a small number of examples of Bos sundaicus, ${ }^{24}$ which were imported from Timor by the English occupants of the fort. After the withdrawal of the English the freely roaming cattle increased tremendously, because of the favourable conditions offered by the swampy areas of the interior and the lack of enemies - dingoes do exist, but they are not numerous - so that now hundreds of them are shot annually to make use of their skins and horns. ${ }^{25}$ The shooting rights have been leased to a gentleman in Sydney in whose service are two buffalo-hunters. They are working on the island and carry out the transport of the skins to Port Darwin. These hunters, two brothers Cooper, ${ }^{26}$ typical adventurers of the Australian bush, have erected a big camp in the centre of the island. There one of them takes

23 The following translation is from Klaatsch 1907a:674-684. See also Klaatsch 1907c, which contains some of the text now published. This paper was given in person (in English) by Professor Klaatsch at the 1907 AAAS meetings in Adelaide. There are no footnotes. There are seventeen plates, of which seven were taken on Melville Island; one is of the graveposts.

24 Bos sundaicus. This name (correctly Bos sondaicus) formerly used for Banteng, a species of wild cattle living in Southeast Asia. In its domesticated form, especially on Bali, is known as the Bali Ox. The rules of zoological nomenclature now require Banteng to be called Bos javanicus. Bali Cattle were brought to the Port Essington settlement, ran wild after its abandonment, and are still found on the Cobourg Peninsula. I do not know of their ever having been on Melville Island, nor do I know of any Humped Cattle (Bos indicus) there. There are, of course, buffalo (Bubalus bubalis) on Melville Island, brought originally from Sundaland (actually Timor, I think). Klaatsch may have meant buffalo when he wrote Bos sundaicus; if so, it is an example of how longstanding is the sometimes casual attitude of anthropologists to the correct identification of wild fauna. [Note supplied by Colin Groves.]

25 The cattle have been imported to the mainland also. In the area of Port Darwin they are used as draught animals. [Original note by Klaatsch, hereinafter indicated by $K$.]

26 See Australian Dictionary of Biography (ADB). Robert Joel (Joe) Cooper (1860-1936), born South Australia, went on a buffalo-shooting expedition to Melville Island in 1895, with brother George Henry (Harry). Joe was speared in the shoulder by Aborigines and they withdrew to the mainland, taking with them by force four Tiwi (two men, two women). In 1905 the brothers returned to Melville 
charge of the hunting, aided by a group of natives, while the other hauls the spoils to the mainland in a little sailboat of only two tons. This ship, and this man as my companion, were the only support I could obtain in order to make the journey to the island. With them I carried out in the second half of September a fourteen-day expedition, which I have to count among the most interesting episodes of my whole journey.

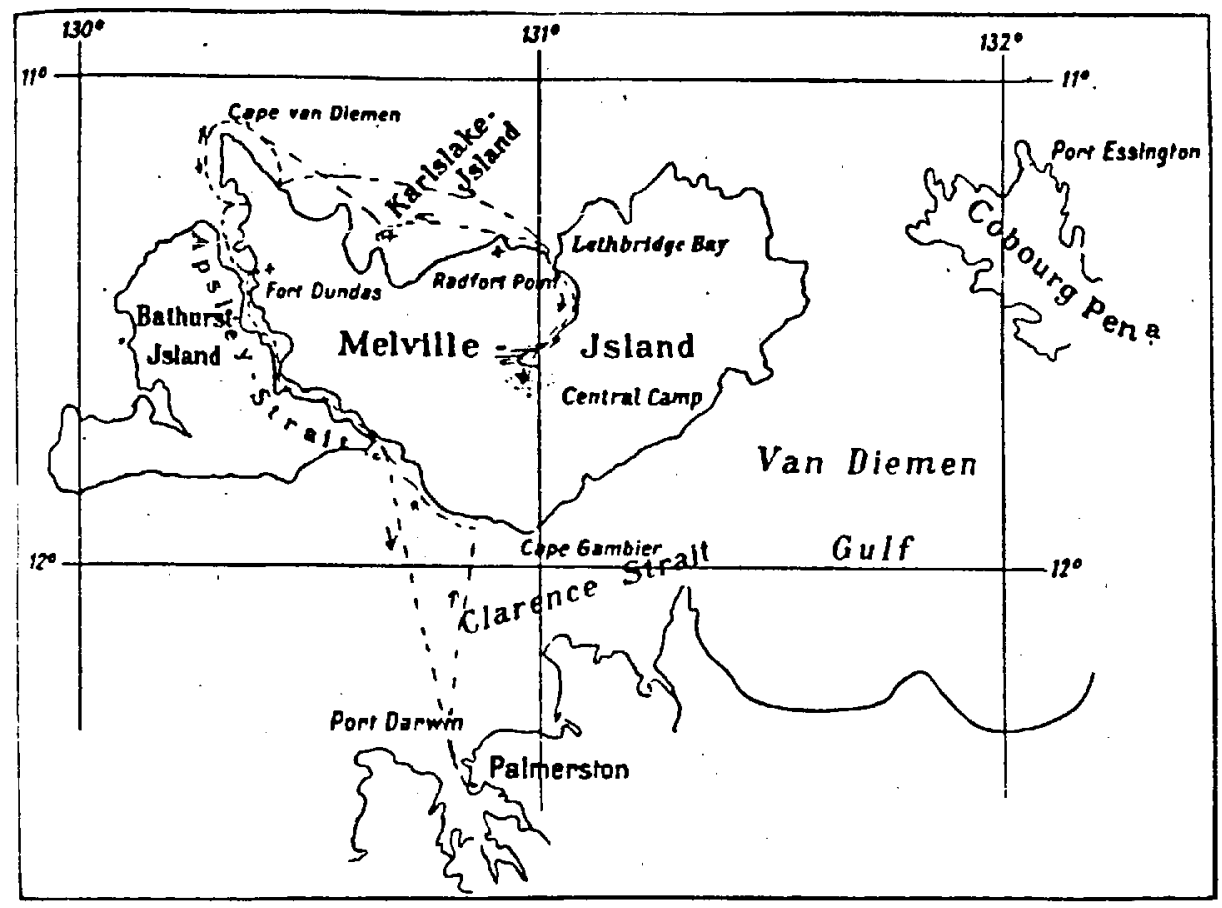

Sketch map of Melville Island. The interrupted line indicates my toute, the crosses mark the locations where I found grave monuments.

When we left Port Darwin on the night of 18 September, in our nutshell, all the space on the boat was completely taken up, as we had seven natives on board, two of whom were from Melville Island.

(Footnote 26 cont'd)

Island with a bodyguard of Port Essington Aborigines, and stayed ten years taking a thousand buffalo a year. (There is no mention in $A D B$ of Harry being killed in 1906 or 1907.) Joe Cooper was known as 'The King of Melville Island'. He helped Baldwin Spencer and J.A. Gilruth (Commonwealth Administrator of the Northern Territory 1911-1912) in their expeditions to Melville Island. Joe Cooper was Sub-Protector of Aborigines from 1911 to 1916 but resigned when his bodyguard was accused of intimidating the Tiwi. 
We needed one day and two nights to cross the Clarence Strait and not until the 20th in the morning did we reach the south coast of the island in the vicinity of Cape Gambier. I was pleased to see already, from a distance, a group of about twenty natives on the shore. Their black bodies contrasted sharply with the white stripe of the sandy beach, and when we approached all of the natives jumped into the water and soon surrounded our ship.

They were all men, of young or middle age, and also two boys, but there were no women. Like wild children they jumped up and down in the water, raising their knees in a very strange way, similar to the way it is done in some corroboree dances. Only later did I have a chance to see the interesting picture in the already mentioned work of Captain King - the discoverer and namer of Melville Island - in which he presents a very similar scene of landing and the same kind of jumping.

The lapse of more than eighty years since that time has not robbed the black inhabitants of any of their wild happiness. What a difference, compared to the fate of the majority of all the natives in the other coastal areas.

They were splendid figures with wild grins that surrounded the little craft and received the presents with childlike eagerness, especially the iron axes that I had brought as an exchange for spears, etc. Some of the group were well known to my white companion. Joe Cooper, the buffalo-hunter, has a friendly relationship with the blacks, although ten years ago he had received a dangerous spearwound from them, an event he had kept secret from me. The spears of Melville Island are strange; they are the heaviest and the most artistically worked spears in the whole of Australia. The head is formed by a broad flattened part, the edges of "which are cut up into about fifteen to twenty barbs. This part is painted beautifully with red, yellow, and white.

Strangely enough, this mighty weapon is thrown without a spear thrower - the woomera is completely absent from Melville Island. These spears serve only for fighting, not for hunting. One would have expected that the Melvillians would have used them to spear the cattle, but to my surprise I was informed by Joe Cooper that the natives of the island never hunted these animals. It was the buffalo-hunters who introduced them to eating their meat. ${ }^{27}$

The pattern of the body-scars on Melville Island differs from that on the mainland and it consists of short, oblique lines, converging in acute angles, reminiscent of the arrangement of leaves.

I assume that it has to do with an imitation of the barbs on the spears. Once, on the beach of the northern coast of the island, I found a sepia on which there was a drawing of the same pattern. Recently some Melvillians have adopted the oblique cuts of their brothers on the mainland, in order to appear more modern.

Regarding my black visitors I noticed the similarity of the facial features of the various individuals. This is characterised by a broad face with prominent cheekbones, and supraorbital ridges that are clearly visible through the skin in a way rarely found. The expression

27 This observation speaks against the assumption that the natives in other areas have started spearing cattle by themselves; probably they were only led to do so after they had been punished for the assumed crime. At the mission station close to Beagle Bay there are about 2000 head of cattle and the missionaries have never lost one due to the natives. In Australia one can often hear the foolish opinion that the natives of Melville Island are as strong as they are because they nourish themselves with wild cattle! $[K]$. 
of the face suggests a mixture of humour, artfulness, and wildness. Their hair was dusted yellow and their faces were partly painted.

Just as at this first encounter, I also had an excellent relationship with the natives later on. Joe Cooper understood their dialect to some extent, but he did not know it well. Verbal communication with the blacks was out of the question for me and, as always in such cases, the communication was limited to gestures. As I had experienced on the islands in the Gulf of Carpentaria, the initial greeting consisted here also in the touching of the white man by the black. In my particular case, the happiness about my good condition of nourishment was expressed with a big grin.

Once I observed a strange happening. An older man came to our ship with two younger men. We gave them biscuits. The older man did not touch them but let them be put into his mouth by his companions. Now I tried the same and the black guest accepted this kind of service by me as something completely normal. I don't know whether a certain custom is behind that.

Four blacks from our boat crew were put ashore in the area of Cape Gambier with the order to go to the central camp of the other brother Cooper and to inform him of our arrival, so that he could send riding- and pack-horses to our place of landing. After we had said goodbye to our black visitors, who had kindly helped us get the boat out, we entered Apsley Strait, which separates Melville Island from Bathurst Island. Before the voyage of discovery of Captain King, Melville Island was considered to be part of the mainland. When King entered Apsley Strait from the north, he regarded it as a big river, until he reached, in the south, the open sea again, and thus recognised the island character of the area. At the southern exit of the strait there is a small island (Buchanan Island), which King named Pelican Island because of its abundance of birds, which even today is remarkable. We went ashore here and sent the blacks to the island in order to get turtles. They regularly used to return from such missions heavily loaded with spoils.

Passing through Apsley Strait took us two days. The voyage through the narrow strait was very tiresome as the wind was usually only light and we often had to resort to the oars. On the eastern shore of the strait, i.e. Melville Island, is the site of the old fort, of which only a heap of bricks remains. The mighty eucalyptus forest has overgrown everything. We have at our disposal the reports of the two officers who founded and dissolved this fort, Captain Bremer, 1824 and Major Campbell, 1829.

However, their information would have been completely forgotten and their remarks about the strange burial sites of the Melvillians further ignored if I had not had the luck to rediscover them. When going ashore in the vicinity of the old Fort Dundas, about a few hundred paces from the shore, I hit upon a group of nine wooden pillars which surrounded an oval, slightly raised, area of earth. They were of differing height, the tallest reaching a height of about three metres. Not one pillar equalled another in shape. One had an upper addition, shaped more or less like a mushroom, another one ended in two points. Another showed a tangential cut-out in the form of a niche; another one was cut open in its centre, so that only two thin poles were left as a connection between the lower part and the upper one, which also ended in a high pointed tip.

I cut off the upper part of this monument and took it with me; now it is one of the best pieces of my collection. Being excellently painted, it serves as a good example of the characteristics of these pillars. However, due to the smallness of my boat, I could not transport more examples. 
The painting consists of ornaments which are carried out in white, red and yellow. On the cylindrical surface of the upper part of the pillar, the same ornament recurs four times. The pillars are made with the help of fire and it appears that sharp pieces of shell have been used as tools, as I have found them on camp grounds. On Melville Island, stone material is completely absent and the inhabitants exist even today in a 'pre-eolithic' state, which clearly shows that the development of mankind could take place even without eoliths and that consequently the whole excitement in this respect is actually of quite little real significance.

These graves with pillars had already been seen by Captain Bremer and Major Campbell; ${ }^{28}$ they were also aware of the objects deposited on or near the pillars. ${ }^{29}$ When I was there, deep baskets of bark were put over a number of pillars. They were painted in a similar way to the pillars and each one had in two places a roundish drilled hole, the edges of which were sewn and enforced by plant fibres. The young Melvillian who accompanied us and who could speak some English gave us the following information: as indicated by the water vessels a woman was buried here and, because the bark baskets contained drilled holes, she must have been speared. On my suggestion he dug for the skeleton with his hands. Making only a very small hole, he hit the skull precisely; he must have guessed the location from a sign which was not apparent to me. The dead person was a very young girl who cannot have been older than eleven years and who presumably became the victim of a love tragedy.

Luckily, we had remained unnoticed by the blacks during our grave violating enterprise. However they must have soon noticed what had happened because, after we had finally stowed away our spoils on the boat and had continued with our journey, we wanted to stop at an appropriate place to pick up water; it had already got dark, when our blacks turned our attention to little flashes of light that started to appear in the thickets of the shore. These were the fire-sticks in the hands of the natives who followed us. Cooper postponed the landing until the next morning, remarking dryly that he did not wish to give the blacks any 'opportunity'.

I later found two more graye-sites. The second one I encountered on the return journey along the north coast, on the little island of Karlslake. Here our boat was stranded for a few hours on a coral reef. We waded to the shore and not far from it appeared a grave-site, again with nine pillars, which, however, had been partly destroyed by fire and fallen down. The same variation of shapes, as in the previous case, was still recognisable; there were no deposits, however.

28 Bremer's report, 1824, is available in print in Russell's Genesis of Queensland, pp. 34-35. 'On Bathurst Island we found the tomb of a native; the situation was one of such perfect retirement and repose that it displayed considerable feeling in the survivors who placed it there; and the simple order which pervaded the spot would not have disgraced a civilised people. It was an oblong square open at the foot, the remaining end and sides being railed round with trees seven or eight feet high, some of which were carved with a stone or shell, and further ornamented by rings of wood also carved. On the tops of these posts were placed the waddies of the deceased; the grave was raised above the level of the earth, but the raised part was no more than three feet long. At the head was placed a piece of a canoe and a spear and round the grave were several little baskets made of the fan palmleaf, which from their small size we thought had been placed there by the children of the departed. Nothing could exceed the neatness of the whole; the sand and the earth were cleared away from its sides and not a scrub or weed was suffered to grow within the area.' [K, corrected $]$

29 Major Campbell 1829, in Russell's Genesis of Queensland, p. 628: 'The burial place is circular . .., it is surrounded by upright poles, many of which are formed as top like lances or halberts, 14-15 feet high and between this spears and waddies of the deceased are stuck upright in the ground.' $[K$, corrected] 
Digging unearthed a beautiful skull, of a strong man, of middle age, the facial part of which showed very clearly the striking facial features of the Melvillians. The skeleton rested on the right side, and this side was partly destroyed, and the same was true for the skull. The teeth were complete, no incisors having been removed, contrary to what could have been expected according to Campbell's report. ${ }^{30}$

With respect to the third site, located at the north coast, at Radford Point, I cannot really prove that it is a burial site, but the two monuments found there resemble very closely those described above. The ground showed no irregularities, however, and digging did not bring forth any bones. Perhaps this is a very old grave-site and the remains have disappeared, or perhaps it is a site to be used at a later time. Next to each monument, facing one another, there was a waddy stuck in the ground, and between them lay two sounding sticks, such as are used in the corroboree to mark the beat. The taller of the pillars was nearly six feet high. It was of the type with a hole in the middle and an upper addition, connected to the lower main part by two thin poles only. I cut off the upper part and took it with me. The pillar was daintily painted with red and yellow colour. The lower main part showed five levels, separated from one another by red rings. In between there was a series of little red rings, circling the pillar, all of it applied on a yellow foundation. The upper part had intermittent red and yellow areas. The second monument was of the type of the mushroom-shape, the stem of the mushroom, however, being furthermore surrounded by a protruding ring. Only in this part, and also on the upper circumference of the mushroom hat, red colour had been used, the lower part showing yellow figures of extremely great diversity - circles, half circles, lines, round areas, horseshoe-shaped patterns, etc. - painted on the natural grey of the wood.

I have not yet reached a definite opinion as to the importance of these Melville Island monuments rediscovered by me. So far, I have not found any indications that these occur in the same shapes and arrangements on the mainland. However in Port Darwin various gentlemen gave hints pointing in this direction, especially regarding the region of Van Diemen Gulf, east of Port Darwin, and south of the Coburg Peninsula, but these statements were very vague. The only thing that I can consider more or less comparable with my findings is a painted, low, simple, cylindrical, wooden pillar in the Museum of Adelaide [South Australian Museum], which is supposed to have come from a grave-site near the MacArthur [McArthur] River in the region of Borroloola (Gulf of Carpentaria, Northern Territory).

The most obvious assumption seems to be that the pillars are meant to be stylised representations of human figures, and consequently may represent relatives or ancestors of the deceased. The shape of the mushroom-hat reminds us easily of the head of a human figure. The two poles connecting the upper and the lower parts have perhaps something to do with the idea of arms and in the case of the niche-shaped hole, the thought of depicting a female sex opening seems not too far-fetched.

Regarding possible connections between the grave-pillars and things outside Australia there are a number of aspects to be considered, but $I$ have not yet screened the literature throughly enough on this point.

30 Campbell 1829 , loc. cit., p. 625: 'All these, who have reached the age of puberty are deficient in an upper front tooth ... I also noticed nothing like this among the living. I noted the absence of any kind of penis mutilation; about this point neither Bremer nor Campbell make any remarks. $[K]$ 


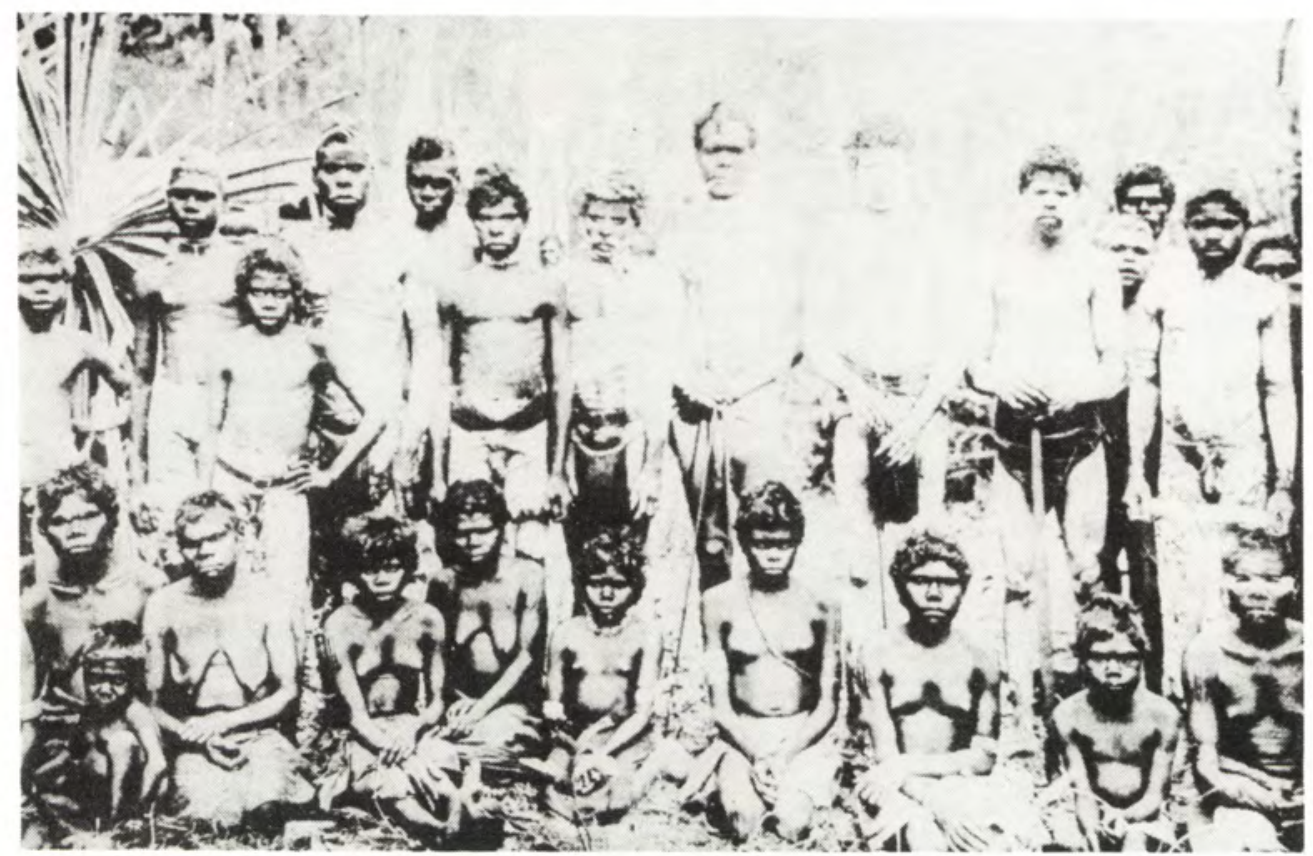

'Central Camp, Melville Island, mainland and island natives'

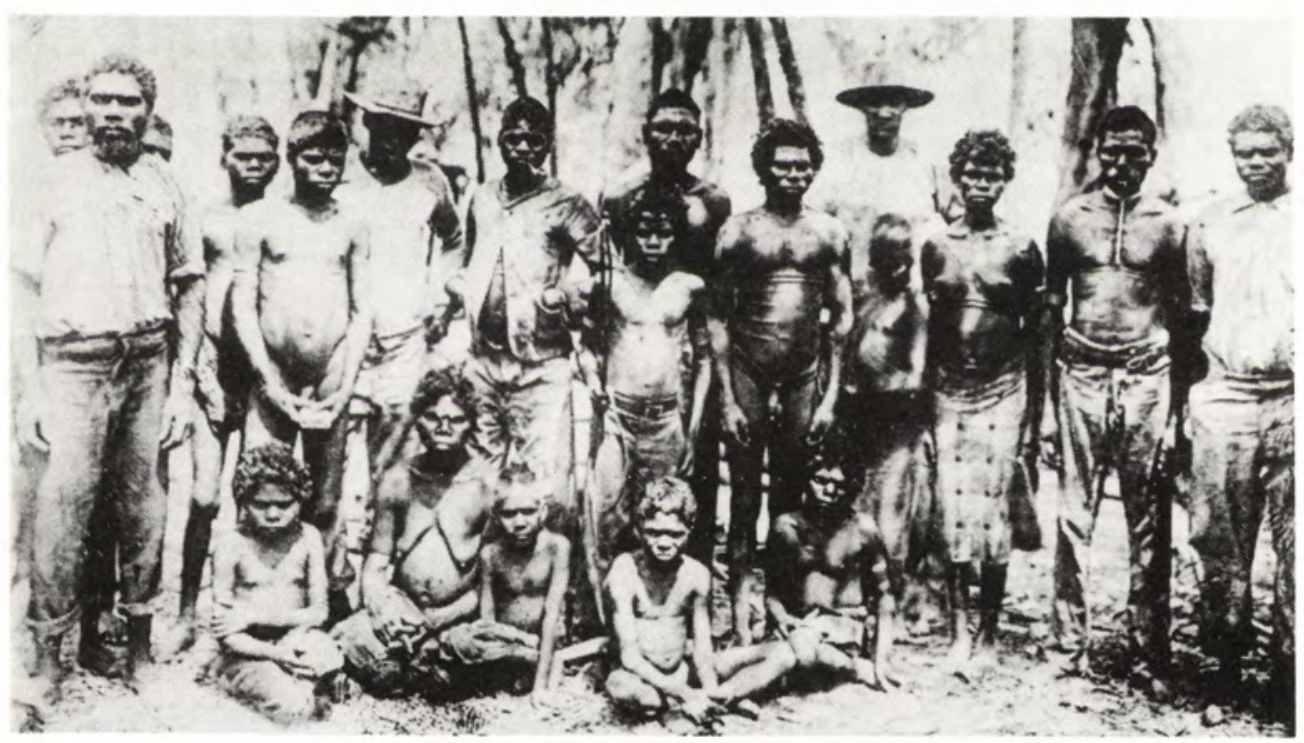

'Natives of Jessie River, Melville Island'

Plates from Klaatsch 1907, courtesy of Australian Institute of Aboriginal Studies 


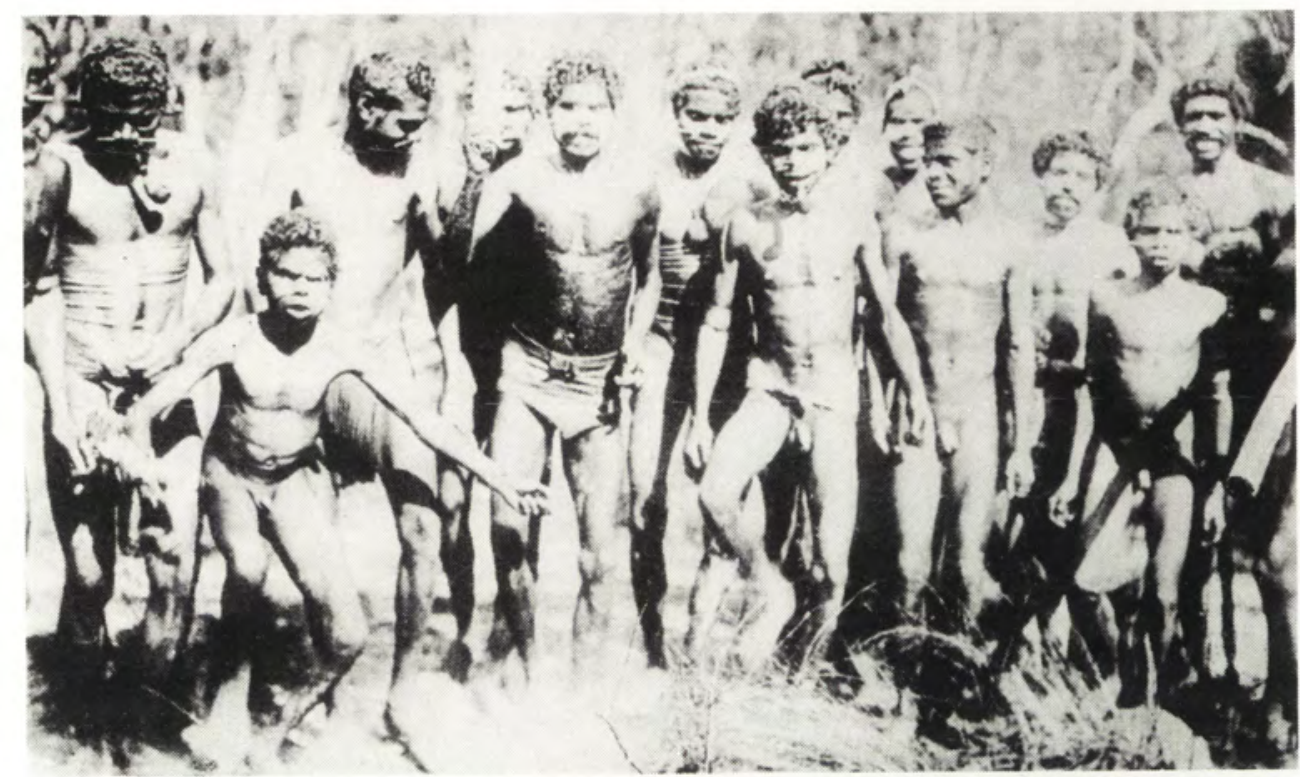

'Natives dancing, Melville Island'

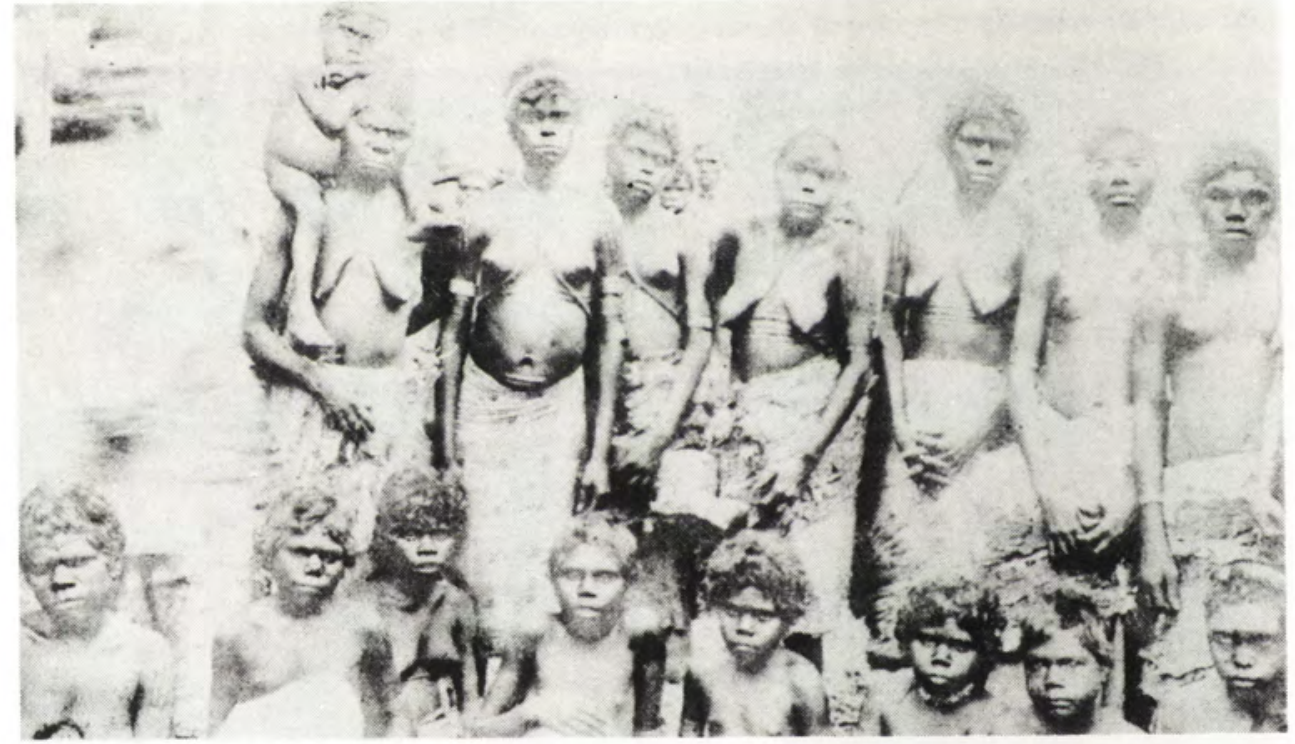

'Native women, Melville Island'

Plates from Klaatsch 1907, courtesy of Australian Institute of Aboriginal Studies 
A gentleman in Adelaide, who had listened to my talk at the Congress there, directed my attention to sacred pillars which he had found on the Solomon Islands, and of which he gave me an excellent photograph. These monuments are about five metres and more high and terminate in the upper part in a human head shape, whereas lower parts of the body are only vaguely indicated. The photograph shows a figure which carries on the head a kind of hat, reminiscent of the mushroom hat shape of Melville Island. These human pillars are located on sites where numerous skulls are assembled.

Another similarity I noticed recently when reading an article by $\mathrm{H}$. Siedel, ${ }^{31}$ Berlin, about the New Hebrides. Here the village drums are represented, carrying human faces and having a slit-shaped opening in the front. The perspectives that open up in connection with the development of human statues from grave-trees must be dealt with some other time.

On 22 September we circumnavigated Cape Van Diemen, the northernmost point of the island; the name goes back to Tasman's voyage of discovery. On the north coast there appeared some natives who followed the ship for some time. We tried to attract them by calling 'pongi, pongi', i.e. good friend, but in vain. On the sand of the beach one of them performed extremely grotesque dancing movements, swinging his spear and then suddenly disappearing. Here again my attention was drawn to the extreme bending movements of the knees. A few weeks earlier a Japanese man from a pearl-fishing boat had been speared at this place, and the natives might well have feared that we were sent to punish the crime. By the afternoon of 23 September we had reached the mouth of the only major river which comes from the interior of the island. This river has not been geographically described so far and it does not yet have a name, apart from that of a black beauty, by which the buffalohunters refer to it. This lubra ${ }^{32}$ was with a group of a dozen natives, men, women and children, who awaited us at the mouth of the river. They were put on board with their three dogs, so that we sat really packed together like sardines. Two strong blacks pulled the oars, another one was placed with an axe at the front end of the boat. He had the task of making a way for the boat through the mangrove thickets which grew over the river at some places like a roof and prevented the mast from passing through. With each branch which crashed down onto the boat hundreds of green ants came out of their nests in the leaves and revenged this breach of domestic peace by biting us fiercely. At nightfall we cast anchor. We waded through the mud of the mangrove swamp to the shore and climbed to the land to establish camp. I have never spent a worse mosquito-ridden night. I was happy when the voyage continued at daybreak. The river widened into a vast swamp, in which the buffaloes wallowed and huge numbers of wild ducks and geese appeared.

31 H. Seidel, 'Die politische und wirtschaftliche Lage auf den Neuen Hebriden' [The political and economic situation in the New Hebrides], Globus, vol. 91 , no. 18, 9 May 1907, p. 283, fig. 4: 'The idols still existing today are mostly wooden figures two to three metres high, of ten of obscene character, standing close to the tabu-houses under the shade trees at the end of the village.' According to A. Basssler's description, 'these drum-trees are hollowed-out logs, often in groups of twenty, several metres high and with a slit in the front. By beating them with a heavy wooden club, they give a sound, and as they are toned in different ways, it is possible to play on them a simple melody of the New Hebrides. The logs are firmly driven into the ground and are often artfully carved, the upper end then representing an idol or another figure.' The slit is worth noting, and this figure also calls my attention to the fact that in one of my cases the sounding sticks were found next to the monuments. The drum-trees of Java etc. that are now beaten to mark the hour also have this slit, and remind us of these village drums' of the New Hebrides. [K]

32 The German text gives 'Lubra'. 
At the landing-place we were awaited by the brother Cooper, accompanied by a big number of blacks and horses. To my surprise the boat was left without any kind of cover. Over a little elevation we then went on horseback for about nine English miles towards the central camp. A big caravan of natives, partly from the mainland, partly from the island, carried the provisions and the instruments. The elevation had a vegetation of light eucalyptus bush and the ground was covered with conglomerates of laterite formation. Shortly before we reached the camp, the landscape changed. After crossing a small river, all of a sudden we found ourselves in the middle of a marvellous stand of huge melaleucas, which formed the canopy to the pandanus and fan-palms. In the truly idyllic, secluded central camp I spent two quiet days in friendly and close contact with the blacks; they soon understood the purpose of my exchange trade and in a short time I had assembled a nice ethnographic collection. With the leaves of the fan-palm, using a bone-needle made of the kangaroo-fibula, the women and girls made those little baskets that Bremer mentions as grave-deposits. The same baskets also occur on the mainland. ${ }^{33}$

The women of Melville Island walk about completely naked. The only time they cover themselves is when they participate in a dance; then they hold a piece of melaleuca bark (paper-bark) in front of the lower part of their body, as a pubic cover. As to their facial and body paintings the Melvillians and the inhabitants of the mainland differ in various respects. Among the women I have found a kind of facial painting that - as far as I have researched this point so far - does not occur elsewhere in Australia. On the cheeks, and sometimes also between the mouth and the chin, little roundish or oval-shaped areas are set apart by painting around them with a colour, e.g. red. The inside is then filled in with dots in another colour, e.g. yellow. These figures can be limited to one half of the face, or they can appear on both halves, then forming separate areas, or they can extend from one side to the other over the chin. By accident, my attention was drawn to a strange resemblance between this kind of body decoration and one of New Guinea. From a representative of Burns Philp in Sydney, I received some photographs in which women from Hula, British New Guinea, are shown; these women have quite similar colour ornaments on their cheeks. The only difference is that the inner area is not filled in with dots, but seems to be evenly covered with one colour.

The women of Melville Island change their colour decorations each day, always inventing new combinations. They spend a considerable amount of time on this work, also helping one another. Cooper pointed out that they believe themselves to be much more beautiful as a result.

The eye and forehead areas get painted with different colours, the former usually with red, the latter with yellow. On the forehead they like to wear a kind of star-shaped disc made of dingo hair, often in combination with a headband made of plant fibres. ${ }^{34}$

33 Cf. H. Basedow, Anthropological notes . . (N.W. coast!), p. 38. He describes the baskets of palmleaves of the region of Port Darwin. He also refers to King, Narrative of a Survey..., vol. 1, pp. 111, 112, where, at an encounter with Melvillians in the Apsley Strait, two such baskets were given as presents to Europeans. He also cites the work of Macgillivray: Narrative of the voyage of H.M.S. Rattlesnake . . ., London 1852, vol. 1, p.146, where similar baskets from the area of Port Essington are mentioned. $[K]$

34 The younger women on Melville Island have pleasant facial features, especially the female children are very delightful creatures. The behaviour of these wild girls and women is of great natural charm, elegance and decency. They also have the happy temperament of the men. [K] 
Men may be painted evenly on the whole body with red or brownish colour. Then the area around the eyes is usually accentuated with a differing colour. But the men have also a complicated kind of painting with white, such as I have never seen on the mainland. Leaving out the hands, feet and genital area, they cover the body with a delicate meshworkpattern, so that on first glance, especially with a photograph, one gets the impression of artificial clothing. It is possible that an imitation of European clothing gave rise to this kind of decoration. The natives of the mainland like to cover themselves evenly with white, or red and white together, probably with a desire to imitate the Europeans a little bit.

The central camp was strictly split into two groups, one of which was that of the Melvillians; the other, however, was composed of the blacks whom Cooper had brought as a kind of bodyguard. ${ }^{35}$

Thus I had a good opportunity to observe the differences between them, especially obvious in the kind of dances they performed. With regard to these the people from the mainland follow the normal mode of the corroborees, whereas the people from Melville Island have their very special way of dancing. ${ }^{36}$ Here I found a kind of dance-music which, as far as I know, has never been described, neither with respect to Australians nor to any other native population - that is, the beating of the buttocks with the hands. ${ }^{37}$ This music is made by the whole audience, which surrounds two single dancers in a semi-circle. The latter imitate both animals and people. With respect to the animals, the shark seems to be of special interest to the Melvillians. To imitate it, the two dancers each held a stick in the right and left hand and with extended arms they pressed one end of each stick in to the armpits. Then they vigorously moved around the circle, the right arm, extended towards the front, representing the head of the shark, the left arm held in the opposite direction, the tail. Thus they dart around, apparently looking for prey. Some women and children, holding the pieces of paper-bark in front of their bodies, stamped with the already noted extreme knee-raising movement into the circle, passing between the two shark dancers.

During these dance performances the climax was reached with the imitation, evident at first glance, of the sailors and officers of the old military settlement of Fort Dundas.

One of the two dancers represented a soldier from a ship by continuously kicking backwards and moving his arms as if he were pulling down ropes, whereas the other dancer, in a posture of arrogance, imitated an officer who was giving orders, by majestically moving his hands. ${ }^{38}$

35 I have recently received the news that one of the brothers Cooper, the one who accompanied me to the island, died suddenly, a few months after my journey. Further details are not available, but it is to be feared that Cooper became a victim of the vengeance for the damage done to the graves $[K]$

36 Here I observed for the first time the use of dancing-sticks, which probably also occur at other places. I do not remember, however, that I have seen them described in the literature. The sticks consist of rolls of melaleuca bark and the dancers hit one another, similar to the way it is done at carnival among us. $[K]$

37 Cf. Major Campbell's report, loc: cit., p.625: 'When they express joy, they jump about and clap their hands violently on their posteriors.' $[K]$

38 Cf. Major Campbell's report, loc. cit., p.625: 'They are also very sensitive to any thing like ridicule. They are good mimics, have a facility for catching up words and are gifted with considerable observation,' $[K]$ 
The memory of the military settlement has persisted among them for thre generations, proving that the Melvillians are excellent actors and also that they have a lively tradition. That they are extraordinarily gifted - both physically and mentally - has already been recognised by Bremer and Campbell. ${ }^{39}$

39 Cf. Bremer's report, loc. cit., p.34: 'In their habits, these people much resemble the natives of NewSouth-Wales but they are superior in person...' $[K]$

\section{BIBLIOGRAPHY}

Basedow, Herbert. Anthropological notes on the western coastal tribes of the Northern Teritory of South Australia (monograph, originally published in Trans. Roy. Soc. S.A.). Adelaide, 1907.

Bremer, Captain Gordon. Official Despatch, 1824, in Russell. The genesis of Queensland. 29-37.

Campbell, Major - 'Geographical Memoir ....' in Russell. The genesis of Queensland. 616-633.

Fischer, Eugen. 'Hermann Klaatsch', Zeitschrift für Ethnologie, 47, 1915:384-390.

Hahne, Hans. 'Hermann Klaatsch zum Gedächtnis', Mannus, 7, 1916:366-375.

King, Phillip Parker. Narrative of a survey of the intertropical and western coasts of Australia performed between the years 1818 and 1822.2 vols, London, 1827.

Klaatsch, Hermann. 'Entstehung und Entwicklung des Menschengeschlechts', in Kramer, H. ed. Weltall und Menschheit, vol.2. Berlin, 1903:3-338.

'Mumie aus Australien und Reisebericht des Hrn. Klaatsch aus Sydney', Zeitschrift fur Ethnologie, 37, 1905:772-781 (see also 211-213).

'Reisebericht des Hrn. Prof. Klaatsch . . . Australien (Victoria, Südaustralien, Westaustralien)', Zeitschrift für Ethnologie, 38, 1906:776-800 (see also 157, 708, 1001).

'Schlussbericht über meine Reise nach Australien in den Jahren 1904-1907', Zeitschrift für Ethnologie, 39, 1907a:635-690 (see also 183-184, 415).

'Ergebnisse meiner australischen Reise', Korrespondenz-Blatt der Deutschen Gesellschaft für Anthropologie, Ethnologie und Urgeschichte (Braunschweig), 38 (9-12), 1907b.

'Some notes on scientific travel amongst the black population of tropical Australia in 1904, 1905, 1906', Report of the Eleventh Meeting of the Australasian Association for the Advancement of Science, held at Adelaide, 1907. 1907c:577-592.

'The skull of the Australian Aboriginal', Report. Pathological Laboratory of the Lunacy Department, Sydney. Vols I-III, 1908:47-167.

'Die Todespsychologie der Uraustralier in ihrer volks-und religionsgeschichtlichen Bedeutung',

in Festschrift zur Jahrhundertfeier der Universität Breslau. Breslau, 1911:401-439.

Die Anfaenge von Kunst und Religion in der Urmenschheit. Leipzig, 1913.

Der Werdegang der Menschheit und die Entstehung der Kultur, ed. A. Heilbonn. Berlin, 1920. 2nd edn 1922; 3rd edn revised and enlarged, 'Das Werden der Menschheit und die Anfänge der Kultur', 1936.

Klaatsch, H. and O. Hauser. 'Homo mousteriensis Houseri, ein altdiluvialier Skelettfund im Department Dordogne und sein Zugehörigkeit zum Neanderthaltypus', Archiv für Anthropologie, 35, 1909:287-97. 'Homo aurignacensis Hauseri, ein palaeolithischer Skelettfund aus dem unteren Aurignacien der

Station Combecapelle bei Montferrand (Perigord)'. Prahistorischer Zeitung, 1, 1910:273-338.

Macgillivray, J. Narrative of the voyage of H.M.S. Rattlesnake 1846-1850. 2 vols, London, 1827.

Russell, Henry Stuart. The genesis of Queensland. Sydney, 1888.

Seger, H. 'Hermann Klaatsch als Anthropologe', Prähistorische Zeitschrift 7 and 8, 1915-1916:241-246.

Seide1, H. 'Die politische und wirtschaftliche Lage auf den Neuen Hebriden', Globus, 91(18), 1907.

Spencer, Baldwin and F.J. Gillen, The native tribes of Central Australia. London, 1899.

The northem tribes of Central Australia. London, 1904.

Wegner, Richard N. 'Hermann Klaatsch', Anatomischer Anzeiger, 48, 1915-1916:611-623. 


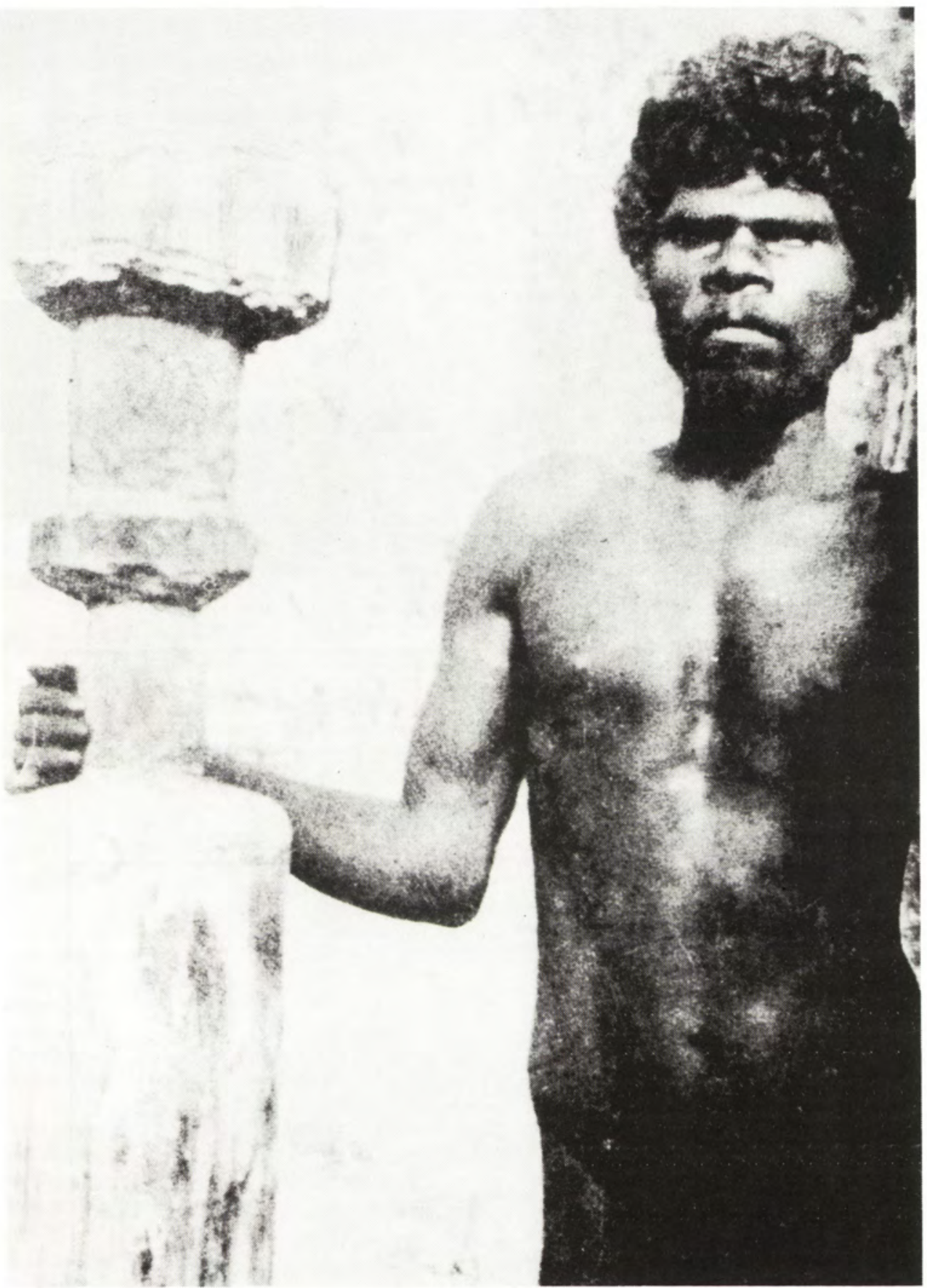

'Upper part of a carved grave monument, from Radford Point, Melville Island, on which a native rests his arm'

Plate from Klaatsch 1907, courtesy of Australian Institute of Aboriginal Studies 